\title{
（95）トイッチェル氏式油脂分解劑に就て.（第26報） 荏油の被分解性亡原料油脂硫酸精製の重要性
}

西 澤 恭助・小野 正 知

上野氏等は，その“油脂の試藥分解齋以關する實用的研究” 第 3 報（本誌，昭和，19，‘47，479）中，與味潹き篔驗結果を報告 せられたるが，就中萑油が分解時間 5 時間にして分解度僅かに $7.22 \%$ に過ぎざるは，それと性質近き亞䀮仁油に關する著者等の 本碓究第 14 報 (本誌, 昭和, 9，37,1334) 中の結果と比較する時 特に眮味梁さを覺えしむ。然れ共兩結果の差が只油脂の構造と組 成及び割合，分解劑と分解條件との差に基因するものとして看過 するには餘りに大なるを感ずるるのあり。氏等の使用せられたる 蕉油つ經歷と精製法とに就ては何等の說明無く，只生油と記載せ られたる所より見れば, 入乎後何等精製を行はる小事無く使用せ られたるるのと解して誤り無かるベし。

著者等はこの奇巽なる結果が萑油の本質に基因するるのに非卞 して，寧ろ著者等の本研究第 24 報（本誌，昭和， $19 ， 47 ， 329$ ) と

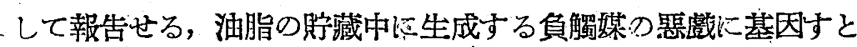
見るを妥當なるへしと考察せんと欲するものなるが，果して然ら ば第 24 報中の結論の適正さを實證するに足る一實例を加一得た らと言ひ得べし。著者等は氏等と同一萑油を大手する事不可能な るにより，約 5 年前竹本製油所より入手せる，鑵入のま〉時々使

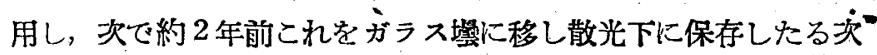
表つ如き性質を有する萑油そのもの，これに既報つ報交中常用世

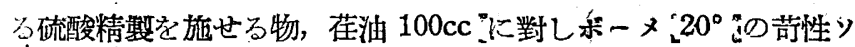
ーダ $20 \mathrm{cc}$ の割合にて常溫に於で添加 $30^{\circ} \mathrm{C}$ 迄加溫精製せる物, 市販の酸性白土を $100^{\circ} \mathrm{C} に 2$ 時間峺燥せるもの $5 \%$ を添加し $100^{\circ} \mathrm{C}$ にて 1 時間攪扫後濾過したる物との 4 種に就さ從來の報文 軲常用せるが如くそれ等の $40 \mathrm{cc}$ に對しイドラピッド $1 \%$ ，硫酸 荏油の性質

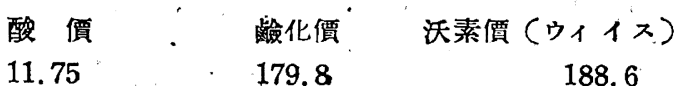

\begin{tabular}{|c|c|c|c|c|}
\hline $2 x .70$ & 分解に & ぼす精謷 & の影蠁 & 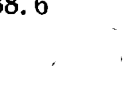 \\
\hline & 原油 & $\begin{array}{l}\text { 硫 酸 } \\
\text { 精製油 }\end{array}$ & $\begin{array}{l}\text { アルカリ } \\
\text { 精製油 }\end{array}$ & 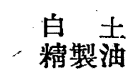 \\
\hline 前酸価 & 11.75 & 10.77 & 1.75 & 10.42 \\
\hline & 11.79 & 64.12 & 2.68 & $11^{\circ} .78$ \\
\hline
\end{tabular}

$1 N$ を含有する水溶液 $20 \mathrm{cc}, 95^{\circ} \mathrm{C}$ 摫拌約 $500 \mathrm{rev} / \mathrm{min}, 5$ 時間な る分解試驗を行ひ著者等の見解の是非を確せる事としたり。

全く豫想せるが如く，永く散光下に保存せる萑油は含有する負 觸媒の䉆めにイドラピッドと硫酸之による分解を全く阻止せられ たるが，これを硫酸精製せるも、のは相當高度に分解せられたり。 (但しその分解の程度が第 14 報中の他種の油に比し稍々小なる感 あるも目的を異にするを以て今はこれに觸れざる事としたり)。

著者等の行へる條件下に柇けるアルカリ精製若くは白土綪製に 對してては此末知なる負觸媒が安定なるが如き結果を示せり。

郎ちこの結果は上野氏等の結果は氏等が萑油を硫酸精椠せらる゙ 〉事無くそのま〉使用せられたるが爲めに起れる異常現象にしで 決して萑油の本質に非ずして恐らく酸敗の鿺めに生成せる偩觸媒 に基因すべき事， メトイッチェル法による油脂分解泩に對する油 脂統制會技術室に於て作成せられたる基準作業法に於て，油脂の 湪備精製なる項目中「原料油脂不透明及び色相惡きとさは硫酸乃 至白土にて豫備精製の事」と規定せられたるも，本研究の結果に よれば負觸媒の含有は必ずしも不透明化を件はず，哫て硫酸 精 製の必要さを外觀を以て判断する事の不可能なる事と，その確定 には實に廣範圍の實驗を要すぺきる白土精製の無效なるべき事と を筫證し得たりと信ず。

酸敗山茶花油に對する一實驗によれば，その含有する負觸媒が $6 N$ の嚂酸に對してる不安定若くはこれにより除去せらる〉るの なるを示せり。

\section{總括}

蕉油がトイッチェル氏式油脂分解劑に對し特殊の被分解性を呈 するるのに非ずして含有する負觸媒の作用に基因して錯覺せしめ らる入場合あるへさ事, 並にこの負觸媒が白土若くはアルカリ精 製に對しては安定なるが如き結果を示せり。

油脂貯藏中に生成する負解媒が監酸に對しても不安定若くはそ れにより除去せらるつ事を酸敗山茶花油に就きてる確認し得たり 研究費の一部と荏油とを寄贈せられたる竹本製油所に對し感謝 の意を表す。(東北帝大工學部化學工學科 : 昭和20.1.26 受理)

（96）高壓油脂加水分解に關する研究（第 1 報） 水素加壓下に於ける硬化鱝油の亳壓加水分解に就て

\section{米勢 千鶴 男}

㧿來オートクレーヴ法による泊脂分拥に關する報告は其公表せ られたるもの少く僅に上野・程垣（本誌，昭和 $11,39,206$ ); 上 野・稻垣・土川（本誌，昭和 $15,43,236$ ) 及び中江氏等（本誌， 昭和 $9,37,1285 ; 1436$; 昭和 $10,38,12$ ) の報告があるにすぎな い。近年 H. P. Kantmann, M. C. Keller (Fette u. Seifen,
1937，44，42) 及び L. Lascaray (Fette u. Seifen, 1939, 46, 628)等の研究報告がある。從來オートクレーヴに依る加水分解法 は10 氣壓以下の比較的低厴のみで高壓に就ては僅かに E. Böhm の簡單なる數値の記載あるに過ぎない。著者は寒際工業的油脂加

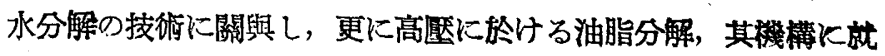

